ROCZNIKI HUMANISTYCZNE

Volume 67, issue $2-2019$

SELECTED PAPERS IN ENGLISH

DOI: http://dx.doi.org/10.18290/rh.2019.68.2-4en

JACEK GOŁĘBIOWSKI

\title{
THE IMPACT OF POLITICAL TRANSFORMATIONS ON THE DEVELOPMENT OF SPANISH CULTURE AFTER 1975
}

After the death of General Franco political transformations in Spain concluded with the first free elections $\left(15^{\text {th }}\right.$ June 1977$)$ in over forty years and with the establishment of a modern parliamentary monarchy which became a powerful catalyst for the activity of the Spanish nation in all fields.

According to Professor Juan Pablo Fusil's opinion, the decentralization of the state expressed in the 1978 constitution resulted in forming one area of freedom that combines the press, theater, cinematography and fine arts, as well as in the intensification of the state's activity for propagating social actions in the field of culture and in reviving regional cultures, as an incarnation of the new idea of Spain being based on the cultural and language varieties of the autonomic communities. ${ }^{1}$

In 1977, the Ministry of Culture was established. Earlier, the Ministry of Information (Ministerio de Informacion), which in the Francoist period was an organ of censorship and control of the cultural sector, had been abolished.

Dr. hab. JACEK GOŁĘBIOWSKI - John Paul II Catholic University of Lublin, Institute of History, Department of Modern History; director of the Center for the Research on the Polish Community and Polish Pastoral Care; address for correspondence: Al. Racławickie 14, 20-950 Lublin; e-mail: jacek@promotor.lublin.pl.

The Polish version of the article was published in Roczniki Humanistyczne 61 (2013), issue 2.

${ }^{1}$ Juan Pablo Fusi, Juliá SAntos, José Luis García Delgado, Juan Carlos JiMÉNEZ, La España del siglo XX (Madrid: Marcial Pons Ediciones de Historia, 2007), 671-672.

Juan Pablo Fusi is a professor of the Complutense University in Madrid, a member of the Centre for Iberian Studies in Oxford and the secretary of the editorial staff of the Revista de Occidente magazine. He was the Director of the National Library in Madrid (1986-1990) and has lectured in numerous Spanish universities. 


\section{THE PRESS}

As a result of political changes, those periodicals connected with Francoism, such as Arriba, Pueblo or El Alcázar, disappeared from the market.

In the years 1976-1977, modern publishing concerns started work PRISA, ZETA and EL CORREO (Bilbao). Modern periodicals started to appear: El Paíz (1977), El Periódico de Cataluña, Diario 16, Deia, Egin, Navarra hoy, together with numerous regional dailies, and since 1989, El Mundo. The appearance of new titles was accompanied by changes in the format, a better quality of paper and the introduction of color. In 1977, 70 dailies were published in Spain whose total circulation amounted to two million copies. In 1994 the number of dailies had increased to 80 titles, and their total circulation exceeded four million copies. The most widely-read ones included El Paiz, El Mundo, ABC, Razón and Vanguardia.

Between 1975 and 1990 a real revolution was conducted in the Spanish mass media. This process was exemplified by the dailies "El País" and "El Mundo", whose weekend circulations exceeded one million copies. The reason for the increase in the circulation was the publishing of attractive supplements devoted to culture, e.g. Babelia, a supplement to El Paiz with a separate edition in Catalan. ${ }^{2}$

\section{RADIO}

On October $3^{\text {rd }} 1977$, the information monopoly of the state RADIO NACIONAL was broken up. On that day the SER broadcasting station emitted its first information program. Since that time we have observed an unheard of quantitative and qualitative development in broadcasting stations. In 1976 the number of stations entitled to broadcast programs was exactly 334 . In 1996 the number had increased to 2,063. The development took place especially in the 1980s, when networks such as SER, RADIO NACIONAL, COPE, ONDA, CERO etc. consolidated their position on the media market. Radio journalists (José María García, Luis del Olmo, Carlos Herrera, Luis Herrero and Julia Otero) enjoyed unusual popularity, were universally known and earned the utmost respect, and the social and cultural information they offered was considered to be extremely valuable.

\footnotetext{
${ }^{2}$ Ibid., 672.
} 


\section{TELEVISION}

Television, like radio, lost its monopoly on information, was subjected to Parliament's control and was adapted to the most up-to-date world standards. In 1982, regional stations started their own emissions, enriching the offer directed at their viewers with problems connected with the lives of the autonomous communities. The Basques were the first to emit programs in euskara, setting up Radio y Televisión Vasca (two TV channels, EUSKAL and TELEBISTA). At more or less the same time the Catalonian government set up TV 3 Televisión Catalana with several theme channels.

In the 1980s, each region had its own radio and television stations also broadcasting programs in the local languages. The appearance of private television channels (the first ones were ANTENA 3, TELECINO and CANAL PLUS) was also a novelty.

\section{THEATER AND THE MINISTRY OF CULTURE}

In 1977, the censoring of theater shows was abolished, which resulted in the rapid development of dramas showing everyday life. In the years 19821994, 670 plays were staged. The theater groups Els Johlars and Els Comedians, as well as the authors Antonio Gala and Fernando Arrabal, became the forerunners of new stage techniques and a new language in contemporary Spanish theater.

On July 4, 1977, the Ministry of Culture was established one of whose main goals (apart from maintaining libraries, museums, exhibitions, noncommercial publishing houses) was to support private cultural initiatives demanding large financial outlays and organizational support.

In 1985 in Brussels, during the Europalia arts festival (which lasted more than three months), Spain presented the European Community with her economic achievements as well as tourist and cultural attractions. The Ministry of Culture prepared a program for this occasion, one showing the essence of Spanish culture. Seven main thematic blocks were presented:

- The Camino de Santiago

- Paintings of the Golden Age (El Greco and Velázquez)

- Goya's paintings

- The most valuable volumes from the National Library

- Picasso's, Miro's and Dali's paintings 
- Federico Lorca's and Juan Ramon Jimenez's poetry

- Luis de Pablo's music

The overriding motto of the project was the neutrality of the state in the cultural sector and the pluralism expressed in a variety of regional cultures. According to the motto, the new tasks accepted by the Ministry of Culture resulted in establishing the National Orchestra (Orquestra Naciónal de España), the Youth Orchestra (La Joven Orquestra), a ballet company and a classical theater (El Ballet Naciónal and La Compaña de Teatro Clasico), setting up a national center of drama (El Centro Dramático Naciónal), initiating the work of a center for new stage trends (Centro Naciónal de Nuevas Tendencias Escenicas). ${ }^{3}$ Exhibitions of Spanish paintings from the $20^{\text {th }}$ century were also organized.

In cooperation with the governments of the autonomous communities the Ministry of Culture brought about a bloom in the number of musical and film festivals, as well as theater reviews. The most important of them are:

- The San Sebastián International Film Festival. ${ }^{4}$

- The International Festival of Music and Dance in Granada.

- The Grec Festival in Barcelona. ${ }^{5}$

- The International Festival of Classical Theatre of Mérida. ${ }^{6}$

- The Almagro International Classical Theatre Festival (Castilla-La Mancha). ${ }^{7}$

- The Festival Internacional de Santander (music, dance and theater).

- The International Religious Music Festival in Cuenca.

- The International Folklore Festival in Ronda (province of Málaga). ${ }^{8}$

- The Autumn Festival in Madrid (theater, music and dance with the participation of guests from all over the world).

- The Bienal de Arte Flamenco in Seville (the most outstanding flamenco artists from all over the world).

- The Huelva Latin American Film Festival.

- The Canary Islands Music Festival (Tenerife and La Palma)

\footnotetext{
${ }^{3}$ Ibid., p. 677.

${ }^{4}$ Created in 1953 and since then it has been one of the most important cinema festivals in Europe. Every year in September it attracts over 100,000 spectators. The honorific award called DONOSTIA has been given, among others, to Susan Sarandon, Jeanne Moreau and Woody Allen.

${ }^{5}$ The greatest open air review of music, theatre and dance in Europe; it takes place in the Grec Theatre in July and August.

${ }^{6}$ Performances are put on at a theater and amphitheater that date from Roman times.

${ }^{7}$ The Festival takes place in the $18^{\text {th }}$ century Corral de Comedias Theater, one of the oldest modern theaters in Europe.

${ }^{8}$ It is the greatest review of ethnic music and authentic folk groups in Spain.
} 
- The Early Music Festival Sevilla. ${ }^{9}$

- ARCO. The International Art Fair in Madrid. ${ }^{10}$

- The City of Valencia International Band Contest.

- The Valencia Festival of Mediterranean Cinema.

In 1986 the Reina Sofía Arts Center was established in Madrid. In Mérida the National Museum of Roman Art was opened - the Museo Naciónal de Arte Romano, and in 1993 the collection of Baron Thyssen-Bornemisza was exhibited at the Palacio de Villahermosa. ${ }^{11}$

The best known projects carried out during that period by the Ministry of Culture include:

- Instituto Valenciano de Arte Moderno in Valencia

- Centro Atlantico de Arte Moderno in Las Palmas

- Centro Gallego de Arte Contemporaneo in Santiago

- Museo de Arte Contemporaneo in Barcelona

- Museo Guggenheima in Bilbao.

The Ministry of Culture also financially supported publishing houses. These actions resulted in an unheard of increase in the editions of new books (from 38,814 titles in 1981 to 51,934in 1995).

The $20^{\text {th }}$ century for Spanish literature was an epoch that could be compared with its "Golden Age" (Siglo de Oro). Multiculturalism artificially suppressed in the Francoist period bore extraordinary fruit in times of freedom. Poets belonging to the famous "Generation of '27", like F. García Lorca, V. Aleixandre ${ }^{12}$ and R. Alberti inspired a new generation of poets and writers with their works. The best known people of letters of the post-war period are, among others: Camilo José Cela, ${ }^{13}$ Miguel Delibes, Gonzalo Torrente Ballester, Buero Vallejo, Manuel Vázquez Montalbán, Juan Marsé and Carmen Martín Gaite.

The closing years of the $20^{\text {th }}$ century in Spanish literature were dominated by writers of the younger generation, including numerous women, which

\footnotetext{
${ }^{9}$ A review of early European music performed on historical instruments.

${ }^{10}$ The Fair belongs to the most prestigious in the world; it is accompanied by the PASARELA CIBELES world fashion show.

${ }^{11}$ Baron Hans Heinrich Thyssen's collection of world painting belongs to the most important private collections in the world. It comprises works painted between 1290 and the 1980s, primarily medieval European paintings, $17^{\text {th }}$ century works by Dutch masters, $19^{\text {th }}$ century paintings from North America and works by Russian Constructivists and German Expressionists. The Spanish government bought them for 375 million dollars and housed them in the converted Palacio de Villahermosa in Madrid.

${ }^{12}$ He received the Nobel Prize for Literature in 1977.

${ }^{13}$ He received the Nobel Prize for Literature in 1989.
} 
was evidence of the profound changes that occurred in Spanish society in the post-Franco era. The most eminent writers of the young generation include: Eduardo Mendoza, Antonio Munioza Molina, Felix de Azua, Julio Llamazares, Jesus Ferrero, Terenci Moix, José María Guelbenzu, Arturo PerezReverte and Javier Marias. Among the women, the novelists Montserrat Roig, Esthera Tusquets, Soledad Puértolas, Lourdes Ortiz and Almudena Grandes are the best known.

Political changes had a strong impact on the development of particular regions. This was clearly seen in the sphere of the development of literature written in the languages of the autonomous communities. The 1980's witnessed a real explosion in literary production in Catalan and Basque, and also Galician.

The most outstanding authors of Catalan literature who contributed to the revitalization of this region's culture include the novelists Josep Pla, Salvador Espríu, Mercé Rodoreda, Baltasar Porcel, Joan Perucho and Joan Brossa, and the poets Pere Gimferrer, Joan Brossa and Jaume Vidal.

According to Professor Carmen Mora, Basque literature in the closing decades of the $20^{\text {th }}$ century experienced a fundamental transformation. It ceased to be local and rural, and became both ambitious and universalist in its subject matter. ${ }^{14}$ The novelists Txillardegui and Atxaga, as well as the poets Luis Seoane, Iglesias Alvariño and Celso Emilio Ferreiro are some of the authors.

The most distinguished novelists who contributed to the development of Galician literature are Alvaro Cunqueiro and Blanco Amor, whereas the group of important poets include Luis Seoane, Iglesias Alvariño and Celso Emilio Ferreiro.

Prestigious prizes and numerous contests are an extremely important factor influencing such a dynamic development of Spanish literature. The most important of them are El Premio Nadal (the oldest award), El Planeta (the one with the highest value), El Prencipe de Asturias (the most prestigious one) and El Cervantes (honoring lifetime achievement).

According to Professor Pablo Fusi, the cultural life of the Kingdom of Spain in the last two decades of the $20^{\text {th }}$ century became an integral part of the European cultural heritage. In the field of music Plácido Domingo, José Carreras and Monserrat Caballé were the unquestioned leaders. This group was joined by the composers Ernesto and Cristobal Halffter, Luis de Pablo,

\footnotetext{
${ }^{14}$ Carmen MoRA, España, ayer y hoy. Itinerario de Cultura y Civilización (Madrid: SGEL, 1995), 73.
} 
Tomás Marco and Ramón Encinas. Great festivals (in Barcelona and Granada, among others) enjoying wide recognition and attention from the European media ${ }^{15}$ provided a strong impetus for the development of Spanish music.

In turn, Spanish cinematography, earlier only known due to the films made by the emigrant Luis Buñuel, ${ }^{16}$ became known abroad thanks to films made by directors belonging to the new generation, like José Luis García (in 1982 he won the Best Foreign Language Film Academy Award for Begin the Beguine), Fernando Trueba (in 1994 an Oscar for Belle Epoque) and Pedro Almodóvar (an Oscar in 2000 for All About My Mother).

The Spanish painters Tapies, Antonio López, Isabel Guerra, Josep Sala and Miguel Barceló also won international recognition. Among the many Spanish museums exhibiting contemporary art, modern ones also appeared: the Museo el Reína Sofia in Madrid, the Joan Miró Museum in Palma de Mallorca, the Dalí Theatre and Museum in Fugueres and the Guggenheim Museum Bilbao.

The autonomous statutes of the 17 regions became a pillar of the Spanish transition to democracy. In the cultural life of Spain a new chapter was also opened. ${ }^{17}$ Spanish culture became the essence of freedom gained during all of the period of transición ${ }^{18}$ and a synonym for a modern parliamentary monarchy.

The rapid development of Spanish culture in the 1980s was noticed by the democratic countries of Western Europe. This was reflected by granting Madrid the title of the European Capital of Culture, which, in turn, provided an impetus for carrying out more prestigious projects.

The Spanish have specialized in organizing great cultural events attracting thousands of tourists from all over Europe. Their foundation and the guarantee of their success was the permanent cooperation of three bodies:

\footnotetext{
${ }^{15}$ Fusi, Santos Julia, García Delgado, JiméneZ, La España del siglo XX, 677-678.

${ }^{16}$ An outstanding film director and scriptwriter working in Spain, Mexico and France. His most important films are An Andalusian Dog (1928), The Young and the Damned (Los Olvidados) (1950), Nazarin (1958, the international prize at the Cannes Film Festival), That Obscure Object of Desire (1977, award at San Sebastian), Belle de Jour (1967, award in Venice), The Discreet Charm of the Bourgeoisie (1972).

${ }^{17}$ The author of the article below discusses the problem more broadly in: Źródła sukcesów wspólczesnej Hiszpanii, cud gospodarczy, monarchia parlamentarna, wspólnoty autonomiczne [The Sources of the Successes of Modern Spain, the Economic Miracle, the Parliamentary Monarchy, Autonomous Communities], in Polska - Hiszpania wczoraj i dziś [Poland - Spain Yesterday and Today], ed. Joanna Kudełko and Cezary Taracha (Lublin: Werset, 2012), 318-336.

${ }^{18}$ The term transición in Spain describes the time of political transformation from the death of General Francisco Franco to the introduction of a democratic constitution ( $6^{\text {th }}$ December 1978) and construction of a modern parliamentary monarchy.
} 
the Ministry of Culture, the government of the autonomous community and local entrepreneurs.

The most prominent example of such action is the Three Cultures International Festival that is held in Murcia. Its organizers invite choirs, theaters, music bands and artists presenting three cultures, Christian, Muslim and Jewish. ${ }^{19}$ The budget of this festival exceeds nine million euro.

To sum up, it should be stated that the most important result of the Spanish political transformations that have influenced cultural changes is the decentralization of the state, making it possible to break the artificial monolith to the advantage of multiculturalism. Establishing autonomous regions has also become a great catalyst for development.

\section{BIBLIOGRAPHY}

Casanova, Julian, and Carlos Gil Andrés. Historia de España en el siglo XX. Barcelona: Grupo Planeta (GBS), 2010.

GOŁĘBIOWSKI, Jacek. Źródła sukcesów współczesnej Hiszpanii, cud gospodarczy, monarchia parlamentarna, wspólnoty autonomiczne [The Sources of the Successes of Modern Spain, the Economic Miracle, the Parliamentary Monarchy, Autonomous Communities], in PolskaHiszpania wczoraj $i$ dziś [Poland - Spain Yesterday and Today], edited by Joanna Kudełko and Cezary Taracha, 318-336. Lublin: Werset, 2012.

MıŁKowski, Tadeusz, and Paweł MachCEwicz. Historia Hiszpanii, Wrocław: Ossolineum, 2002. MorA, Carmen. España, ayer y hoy. Itinerario de Cultura y Civilización. Madrid: SGEL, 1995.

Fusi, Juan Pablo, Juliá SAntos, José Luis García Delgado, and Juan Carlos JimÉnez. La España del siglo XX. Madrid: Marcial Pons Ediciones de Historia, 2007.

\section{THE IMPACT OF THE POLITICAL TRANSFORMATIONS ON THE DEVELOPMENT OF SPANISH CULTURE AFTER 1975}

S u m m a r y

The political transformations in Spain that ended with the free parliamentary elections of $15^{\text {th }}$ June 1977 were a powerful catalyst for the activity of the Spanish nation in all walks of life. Between 1975 and 1990 a real revolution took place in the Spanish mass media and in culture. It resulted in the setting up of modern periodicals (among others, El Pais, El Mundo, Navarra Hoy, Diario la Rioja and many others), over 2,600 radio stations and a network of modern television channels broadcasting programs devoted to the culture and languages of the autonomous communities. The Ministry of Culture established in 1977 supported initiatives promoting the multiculturalism of the Kingdom of Spain, which resulted in the opening of several dozen modern museums, institutes of modern art and the organization of numerous festivals.

\footnotetext{
${ }^{19}$ In the Three Cultures International Festival Lublin artists also took part: the Choir of the Catholic University of Lublin and Marek Sołowiej from Zamość, with an exhibition of his paintings.
} 
The decentralization of the country made it possible to emphasize the multiculturalism of the Spanish autonomous communities that today act as a magnet for 70 million tourists from all over the world.

Key words: Spain in the $20^{\text {th }}$ century; autonomous communities; culture of modern Spain.

\section{Translated from Polish by Tadeusz Karlowicz}

The preparation of the English version of Roczniki Humanistyczne and its publication in electronic databases was financed under contract no. 836/P-DUN/2018 from the resources of the Minister of Science and Higher Education for the popularization of science. 